\title{
A dinosaur ilium from the Late Triassic of Brazil with comments on key-character supporting Saturnaliinae
}

\author{
MAURÍCIO S. GARCIA ${ }^{1,2}$, FLÁVIO A. PRETTO ${ }^{2}$, SÉRGIO DIAS-DA-SILVA ${ }^{3}$ and RODRIGO T. MÜLLER ${ }^{2}$ \\ ${ }^{1}$ Curso de Ciências Biológicas, Centro de Ciências Naturais e Exatas, Universidade Federal de \\ Santa Maria, Av. Roraima, 1000, Bairro Camobi, 97105-900 Santa Maria, RS, Brazil \\ ${ }^{2}$ Centro de Apoio à Pesquisa Paleontológica da Quarta Colônia, Universidade Federal de Santa \\ Maria, Rua Maximiliano Vizzotto, 598, 97230-000 São João do Polêsine, RS, Brazil \\ ${ }^{3}$ Laboratório de Paleobiodiversidade Triássica, Departamento de Ecologia e Evolução, Universidade \\ Federal de Santa Maria, Av. Roraima, 1000, Bairro Camobi, 97105-900 Santa Maria, RS, Brazil \\ Manuscript received on June 16, 2018; accepted for publication on September 16, 2018
}

\begin{abstract}
How to cite: GARCIA MS, PRETTO FA, DIAS-DA-SILVA S AND MÜLLER RT. 2019. A dinosaur ilium from the Late Triassic of Brazil with comments on key-character supporting Saturnaliinae. An Acad Bras Cienc 91: e20180614. DOI 10.1590/0001-3765201920180614.
\end{abstract}

\begin{abstract}
Discoveries in Carnian-aged rocks are establishing a rich and diverse dinosaurian fauna at the so-called 'dawn of the age of dinosaurs' in the Late Triassic of Western Gondwana. Accordingly, Brazilian strata from the Candelária Sequence have contributed extensively to this trend. Here, we present a new dinosaurian specimen (CAPPA/UFSM 0200) from this geological unit. The material was collected at a fossiliferous site that had no previous record of dinosaurs. Our specimen comprises a single ilium, which we describe in detail. Its anatomy is consistent with Carnian sauropodomorph dinosaurs, but differs from coeval specimens by several features, although we do not discard the possibility of these features being the result of intraspecific variation. In part of our phylogenetic investigation, CAPPA/UFSM 0200 was recovered within Saturnaliinae, a group comprised of Carnian sauropodomorphs from South America. However, based on examination of better-sampled coeval taxa, a character (a strong rugosity in the ilium) supporting this less inclusive position might be related to intraspecific variation and so, should be carefully considered. This study increases the distribution of dinosaur remains in fossiliferous units from southern Brazil and adds to the discussion regarding intraspecific variation and its implications in the phylogeny of early dinosaurs.
\end{abstract}

Key words: intraspecific variation, Saurischia, Sauropodomorpha, Upper Triassic, Western Gondwana.

\section{INTRODUCTION}

Upper Triassic units from southern Brazil include the oldest dinosaur-bearing sites worldwide, dating

Correspondence to: Maurício Silva Garcia

E-mail: mauriciossauro@gmail.com

ORCid: https://orcid.org/0000-0001-5317-0140

* Contribution to the centenary of the Brazilian Academy of Sciences. back to the Carnian Stage 237-227 Ma (Langer et al. 2018). Over the last few years, outcrops from the Candelária Sequence (sensu Horn et al. 2014), have provided several exceptional dinosauromorph specimens (e.g. Cabreira et al. 2011, 2016, Müller et al. 2018a, Pretto et al. 2018) from the Hyperodapedon Assemblage Zone (AZ) (Langer et al. 2007). Consequently, it is of paleontological 
interest to further recognize and identify dinosaurian specimens from the localities of this unit, because they hold fundamental data regarding the early evolution and radiation of dinosaurs. So far, the dinosaurian fauna from the Hyperodapedon AZ of the Candelária Sequence is mostly represented by herrerasaurids (Colbert 1970) and early-diverging sauropodomorphs (Langer et al. 1999, Cabreira et al. 2011, 2016, Müller et al. 2018a, Pretto et al. 2018), in which pelvic girdle/hindlimb remains are frequently sampled (e.g. Pretto et al. 2015, Müller et al. 2014, 2015, 2017a). Pelvic elements provide important diagnostic information for these clades (Novas 1996, Sereno 1999), and the identification and comparative description of these bones is fundamental for a comprehensive knowledge on early dinosaurian evolution and diversification.

Comprised of pairs of ilia, pubes and ischia, the unique pelvic morphology of dinosaurs and other dinosauromorphs allowed bipedal posture and cursorial locomotion, resulting in a highly specialized anatomical structure when compared to that of other archosaurs (e.g. Nesbitt 2011, Ezcurra 2016). The ilium is well-sampled in most early dinosaurs and dinosaurian relatives (e.g. Dzik 2003, Langer 2003, Cabreira et al. 2016), which makes it an important source of morphological data in these clades (Langer et al. 2010), even providing key characters that support some groups (Ezcurra 2010, Martínez et al. 2013). Particularly, the observation of a set of traits (especially rugosities related to muscle attachments) present in early dinosaurs and their close relatives raises a series of questions: are these rugosities dependent on intraspecific variation? If so, could they represent an ontogenetic feature? Are these traits reliable as phylogenetic characters (i.e. synapomorphic features), as previously suggested? Do they carry phylogenetic signal at all? Are they present in the same extent in other dinosauriforms? In an effort to assess some of these questions we describe here a partial left ilium that comprises the first dinosaurian specimen from the Piche site (Late Triassic of southern Brazil), in the municipality of São João do Polêsine, State of Rio Grande do Sul, Brazil. Additionally, we provide a comparative assessment of the iliac morphology among early dinosaurs and their kin.

Institutional abbreviations - BMNH, British Museum Natural History, London, UK; CAPPA/ UFSM, Centro de Apoio à Pesquisa Paleontológica da Quarta Colônia, Universidade Federal de Santa Maria, São João do Polêsine, Brazil; LPRP/USP, Laboratório de Paleontologia de Ribeirão Preto, Universidade de São Paulo, Ribeirão Preto, Brazil; MCP, Museu de Ciências e Tecnologia, Porto Alegre, Brazil; MCZ, Museum of Comparative Zoology, Cambridge, USA; NHCC, National Heritage Conservation Commission of Zambia, Lusaka, Zambia; NMMNH, New Mexico Museum of Natural History and Science, Albuquerque, USA; NMQR, National Museum, Bloemfontein; NMT, National Museum of Tanzania, Dares Salaam, Tanzania; PVL, Paleontología de Vertebrados, Instituto 'Miguel Lillo', San Miguel de Tucumán, Argentina; PVSJ, Instituto y Museo de Ciencias Naturales, San Juan, Argentina; SMNS, Staatliches Museum of Naturkunde, Stuttgart, Germany; UCMP, University of California Museum of Paleontology, Berkeley, USA; UFRGS, Universidade Federal de Rio Grande do Sul, Porto Alegre, Brazil; UFSM, Laboratório de Estratigrafia e Paleobiologia, Universidade Federal de Santa Maria, Brazil; ULBRA, Universidade Luterana do Brasil, Coleção de Paleovertebrados, Canoas, Brazil; UMMP, University of Michigan Museum of Paleontology, Ann Arbor, USA; ZPAL, Institute of Paleobiology of the Polish Academy of Sciences, Warsaw, Poland.

\section{SYSTEMATIC PALEONTOLOGY}

Dinosauromorpha Benton, 1985

Dinosauriformes Novas, 1992 
MAURÍCIO S. GARCIA et al.

Dinosauria Owen, 1842

Saurischia Seeley, 1888

cf. Sauropodomorpha von Huene, 1932 sensu

Sereno 2007

MATERIAL

CAPPA/UFSM 0200, a partial left ilium, roughly $75 \mathrm{~mm}$ in craniocaudal length, in which the iliac blade and the pubic peduncle are both incomplete.

LOCALITY AND HORIZON

CAPPA/UFSM 0200 was collected in the basalmost level of the Piche outcrop (29³9'13.84"S; 53²7'38.36”W), in São João do Polêsine, Rio Grande do Sul state, Brazil (Fig. 1). This outcrop is referred to the Candelária Sequence from the Santa Maria Supersequence (Horn et al. 2014), Upper Santa Maria Formation (Andreis et al. 1980). Besides CAPPA/UFSM 0200, this site has also yielded conchostracans (Jenisch et al. 2017), hybodontiformes (Perez and Malabarba 2002), actinopterygians (Perez and Malabarba, 2002), aetosaurs and hyperodapedontyn rhynchosaurs (Langer et al. 2007). The fossil record of this site is compatible with those from the Hyperodapedon Assemblage Zone, in which the upper level of its type-locality was radioisotopically dated as 233.23 $\pm 0.73 \mathrm{Ma}$ (Langer et al. 2018). Therefore, the fauna of the Piche outcrop is considered Carnian in age.

\section{DESCRIPTION}

Most specimens from Argentina and Brazil were examined first-hand and listed in Table I. The overall morphology of CAPPA/UFSM 0200 resembles that of basalmost saurischian dinosaurs (e.g. Langer 2003, Sereno et al. 2013, Cabreira et al. 2016, Müller et al. 2018a), with the exception of herrerasaurids (Colbert 1970, Novas 1994). The acetabulum of CAPPA/UFSM 0200 is not fully perforated and the specimen presents a well-developed postacetabular ala (Fig. 2), as in
A DINOSAUR ILIUM FROM THE LATE TRIASSIC OF BRAZIL

several other basal saurischians (Langer 2003, Ezcurra 2010, Cabreira et al. 2016), differing from herrerasaurids (Colbert 1970, Novas 1994). Theiliac blade is dorsoventrally tall, as in most dinosaurs, and the preserved dorsal margin bears rugosities (possibly related to muscle attachment) which are further described below. A deep concavity is situated on the lateral surface of the cranial portion of the iliac blade, which possibly corresponds to the attachment area of $m$. iliofemoralis (see Hutchinson 2001, Langer 2003). According to these authors, this morphology represents a plesiomorphic trait among dinosaurs, as it is also observed in Marasuchus lilloensis, Herrerasaurus ischigualastensis (Fig. 3k), Caseosaurus crosbyensis, and Thecodontosaurus antiquus. However, in CAPPA/UFSM 0200 this concavity is substantially deeper than that observed in coeval taxa (e.g. Buriolestes schultzi, Pampadromaeus barberenai, Saturnalia tupiniquim). In lateral view, the dorsal margin of the preserved portion of the iliac blade is almost straight, as in Buriolestes schultzi (ULBRA-PVT280) and Chromogisaurus novasi, slightly contrasting with the mostly convex shape present in Saturnalia tupiniquim (Fig. 2, 3).

CAPPA/UFSM 0200 possesses a postacetabular ala that is more prominent than its preacetabular counterpart, a condition shared with several other coeval saurischian dinosaurs, such as Buriolestes schultzi, Saturnalia tupiniquim, Staurikosaurus pricei, and non-dinosaurian dinosauromorphs such as Marasuchus lilloensis, silesaurids, and herrerasaurids (Fig. 2, 3). Both alae possess conspicuous and strong developed rugosities (see below). Although the pubic peduncle of CAPPA/UFSM 0200 is fragmented, the cranial margin of its preacetabular ala probably did not reach the cranialmost extent of the pubic peduncle, a feature that also occurs in sauropodomorphs as Buriolestes schultzi and Efraasia minor, and the herrerasaurids Herrerasaurus ischigualastensis and Staurikosaurus pricei (Fig. 2, 3). 
TABLE I

Specimens and references used in the comparisons. Specimens that were not seen first-hand by any of the authors are marked with an asterisk (*).

\begin{tabular}{|c|c|}
\hline Taxon & Specimen \\
\hline Asilisaurus kongwe & NMT RB176* - Peecook et al. 2013 (Nesbitt et al. 2010) \\
\hline Bagualosaurus agudoensis & UFRGS-PV-1099-T - Pretto et al. 2018 \\
\hline & ULBRA-PVT056 (a putative juvenile individual) \\
\hline Buriolestes schultzi & ULBRA-PVT280 - Cabreira et al. 2016 \\
\hline & CAPPA/UFSM 0035 - Müller et al. 2018a \\
\hline Caseosaurus crosbyensis & $\begin{array}{l}\text { NMMNH P-35995* - Hunt et al. 1998, Baron and Williams } 2018 \\
\text { UMMP 8870* - Hunt et al. 1998, Baron and Williams } 2018\end{array}$ \\
\hline Chromogisaurus novasi & PVSJ 845 - Ezcurra 2010 (Martínez et al. 2012) \\
\hline Efraasia minor & SMNS 12354* - Yates 2003b (Bittencourt et al. 2012) \\
\hline Eoraptor lunensis & PVSJ 512 - Sereno et al. 2013 \\
\hline Guaibasaurus candelariensis & $\begin{array}{l}\text { MCN PV2355 - Bonaparte Ferigolo and Ribeiro } 1999 \\
\text { UFRGS PV 0725T - Langer Bittencourt and Schultz } 2011\end{array}$ \\
\hline Herrerasaurus ischigualastensis & PVL 2566 - Novas 1994 (Bittencourt et al. 2012, Baron and Williams 2018) \\
\hline Ignotosaurus fragilis & PVSJ 883* - Martínez et al. 2013 \\
\hline Ixalerpeton polesinensis & ULBRA-PVT059 - Cabreira et al. 2016 \\
\hline Lessemsaurus sauropoides & PVL 4822* - Pol and Powell 2007 \\
\hline Lutungutali sitwensis & NHCC LB32* - Peecook et al. 2013 \\
\hline Marasuchus lilloensis & PVL 3870 - Sereno and Arcucci 1994 \\
\hline Melanorosaurus & NMQR 1551* - McPhee and Choiniere 2016 \\
\hline Nhandumirim waldsangae & LPRP/USP 0651 - Marsola et al. 2019 \\
\hline Pampadromaeus barberenai & ULBRA-PVT016 - Cabreira et al. 2011 \\
\hline Panphagia protos & PVSJ 874 - Martínez and Alcober 2009 \\
\hline Pantydraco caducus & BMNH P77/1* - Yates 2003a \\
\hline Plateosaurus & SMNS 12250* - Moser 2003 \\
\hline Riojasaurus incertus & $\begin{array}{l}\text { PVL 3808* - Langer Bittencourt and Schultz } 2011 \\
\text { PVL 3809* - Novas } 1996 \\
\text { PVL 3815* - Novas } 1996\end{array}$ \\
\hline Saturnalia tupiniquim & $\begin{array}{c}\text { MCP 3944-PV - Langer } 2003 \\
\text { MCP 3945-PV (Langer 2003, Marsola et al. 2019) } \\
\text { MCP 3946-PV (Bittencourt et al. 2012) }\end{array}$ \\
\hline Silesaurus opolensis & $\begin{array}{l}\text { ZPAL AbIII404/1* - Peecoock et al. } 2013 \text { (Dzik 2003) } \\
\text { ZPAL AbIII 907/6* - Langer Bittencourt and Schultz } 2011 \text { (Dzik 2003) }\end{array}$ \\
\hline Staurikosaurus pricei & MCZ-1669* - Bittencourt and Kellner 2009 (Colbert 1970) \\
\hline Thecodontosaurus antiquus & BMNH R1539* - Benton et al. 2000 \\
\hline
\end{tabular}




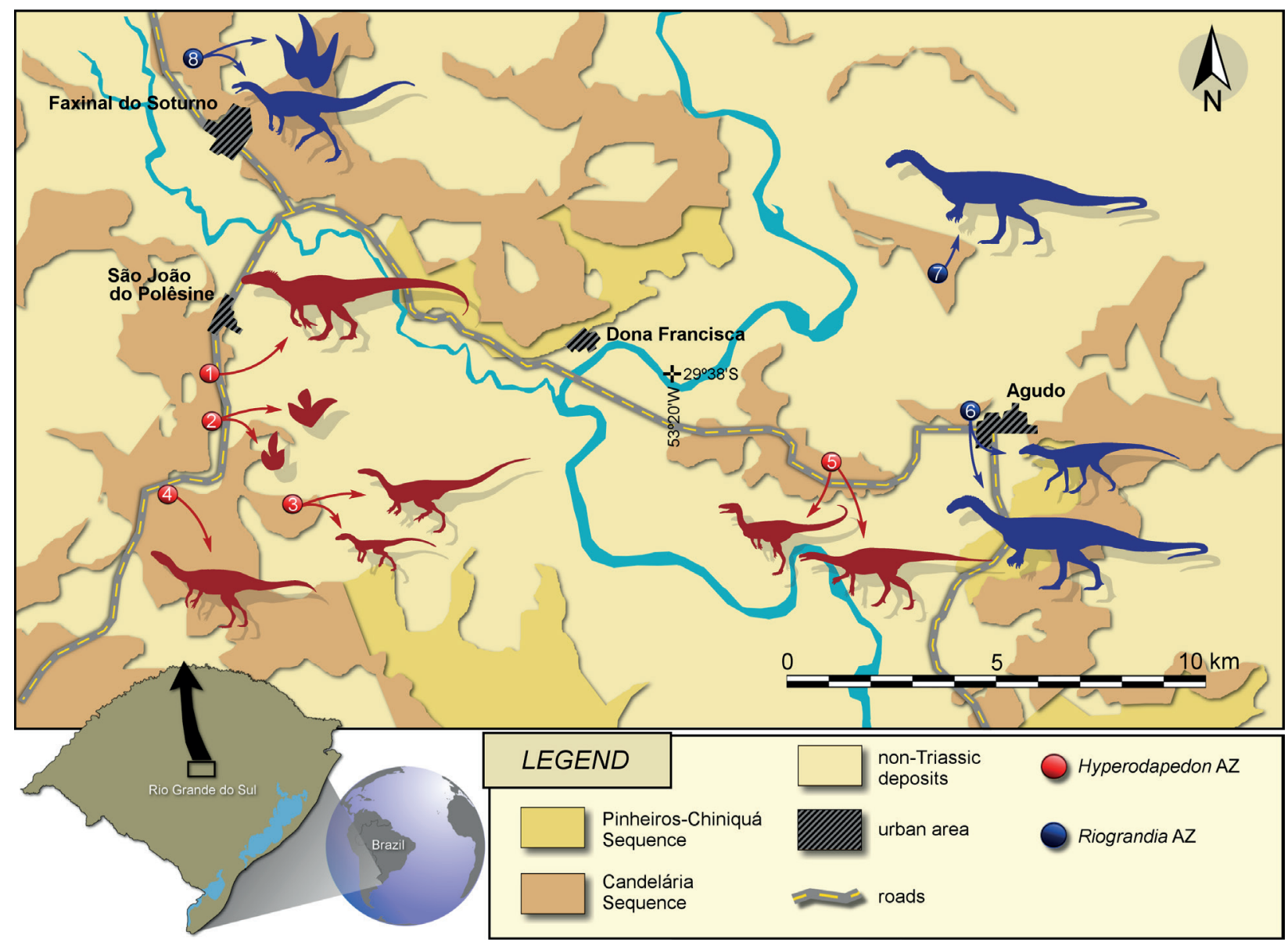

Figure 1 - Map of the São João do Polêsine area, Rio Grande do Sul state, southern Brazil, showing the distribution of dinosauromorph remains in the nearby fossiliferous sites (modified from Zerfass et al. 2007). "Marchezan" site (1), where an indeterminate herrerasaurid was collected; "Predebon" site (2), where tridactyl footprints attributed to indeterminate dinosaurs and to the ichnogenus Grallator were found (da Silva et al. 2008); "Buriol" site (3), where the holotypes and referred specimens of Buriolestes schultzi and Ixalerpeton polesinensis were collected (Cabreira et al. 2016, Müller et al. 2017b, Müller et al. 2018a); "Piche site" (4), where CAPPA/UFSM 0200 was collected; "Janner" site (5), where the holotypes and referred specimens of Bagualosaurus agudoensis, Pampadromaeus barberenai and other dinosauriform remains were collected (Cabreira et al. 2011, Müller et al. 2014, 2015, 2017b, Pretto et al. 2015, Pretto et al. 2018); "Sacisaurus" site (6); whereas the holotype and referred specimens of Sacisaurus agudoensis and indeterminate sauropodomorphs were collected (Ferigolo and Langer 2007); "Wachholz" site (7), whereas the holotype and paratypes of the sauropodomorph Macrocollum itaquii were collected (Müller et al. 2018c); "Linha São Luiz" site (8), whereas referred specimens of Guaibasaurus candelariensis were collected (Langer et al. 2011) and large tridactyl "theropod-like" footprints attributed to the ichnogenus Eubrontes were found (da Silva et al. 2012).

In dorsal view, the cranial portion of the preacetabular ala slightly turns laterally in CAPPA/ UFSM 0200, as in specimens of Saturnalia tupiniquim (MCP 3945-PV and MCP 3946$\mathrm{PV})$ and differing from Buriolestes schultzi and Pampadromaeus barberenai (Fig. 3). The angle of the dorsal portion of the cranial tip in the preacetabular ala differs from that of Buriolestes schultzi, because in CAPPA/UFSM 0200 the preacetabular ala is gently sloped relative to the horizontal plane, whereas in Buriolestes schultzi it is more vertically oriented. Nonetheless, the cranial tip of the preacetabular ala is rounded as also observed in most Carnian saurischians, for instance: Buriolestes schultzi, Saturnalia tupiniquim, Pampadromaeus barberenai and 

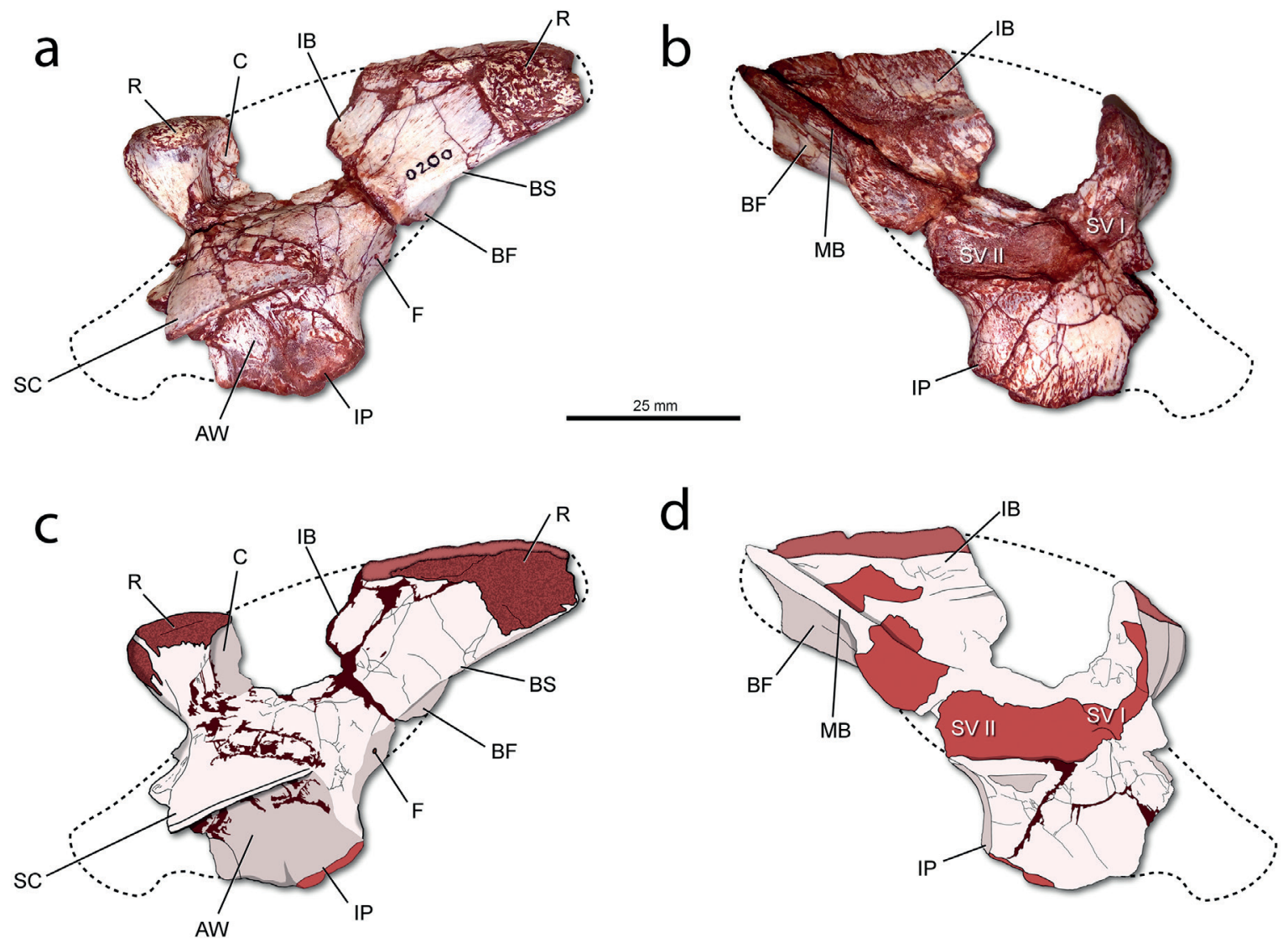

Figure 2 - Photographs and drawings of CAPPA/UFSM 0200, a sauropodomorph left ilium. a, lateral view. b, medial view. c, lateral view. d, medial view. Abbreviations: AW, Acetabular wall; BF, Brevis fossa; BS, Brevis shelf; C, Concavity; CV, Caudosacral vertebra; F. Foramen; IB, Iliac blade; IP, Ischiadic peduncle; MB, Medial blade; R, Rugosity; SC, Supraacetabular crest; SV I, Sacral primordial vertebra I; SV II, Sacral primordial vertebra II.

Nhandumirim waldsangae. This morphology contrasts with the pointed and/or elongated preacetabular ala observed in many post-Carnian sauropodomorphs such as Efraasia minor, Lessemsaurus sauropoides, Melanorosaurus, Pantydraco caducus, and Plateosaurus. Although other saurischians like Bagualosaurus agudoensis and Guaibasaurus candelariensis (UFRGS PV 0725T), and silesaurids as Asilisaurus kongwe and Silesaurus opolensis, present a similar condition that may be result of a taphonomic artifact (Pretto et al. 2018). However, the ilium of Lutungutali sitwensis and some of the specimens of Silesaurus opolensis both give clues of the true aspect of this structure in silesaurids, because they possess more complete ilia (Peecook et al. 2013, Piechowski et al. 2014). Additionally, in CAPPA/ UFSM 0200 the preacetabular ala is shorter than in coeval sauropodomorphs (e.g. Pampadromaeus barberenai, Saturnalia tupiniquim). Laterodorsally, on the preacetabular ala, there is a strong developed rugosity that forms a raised surface which extends to the dorsal margin of the iliac blade (Fig. 3), roughly similar to Chromogisaurus novasi and Saturnalia tupiniquim (MCP 3945-PV, MCP $3946-$ PV), and, to a lesser extent, to Asilisaurus kongwe, Buriolestes schultzi, Caseosaurus crosbyensis, Herrerasaurus ischigualastensis, Ignotosaurus fragilis, Lutungutali sitwensis, and Silesaurus opolensis (see Discussion). 

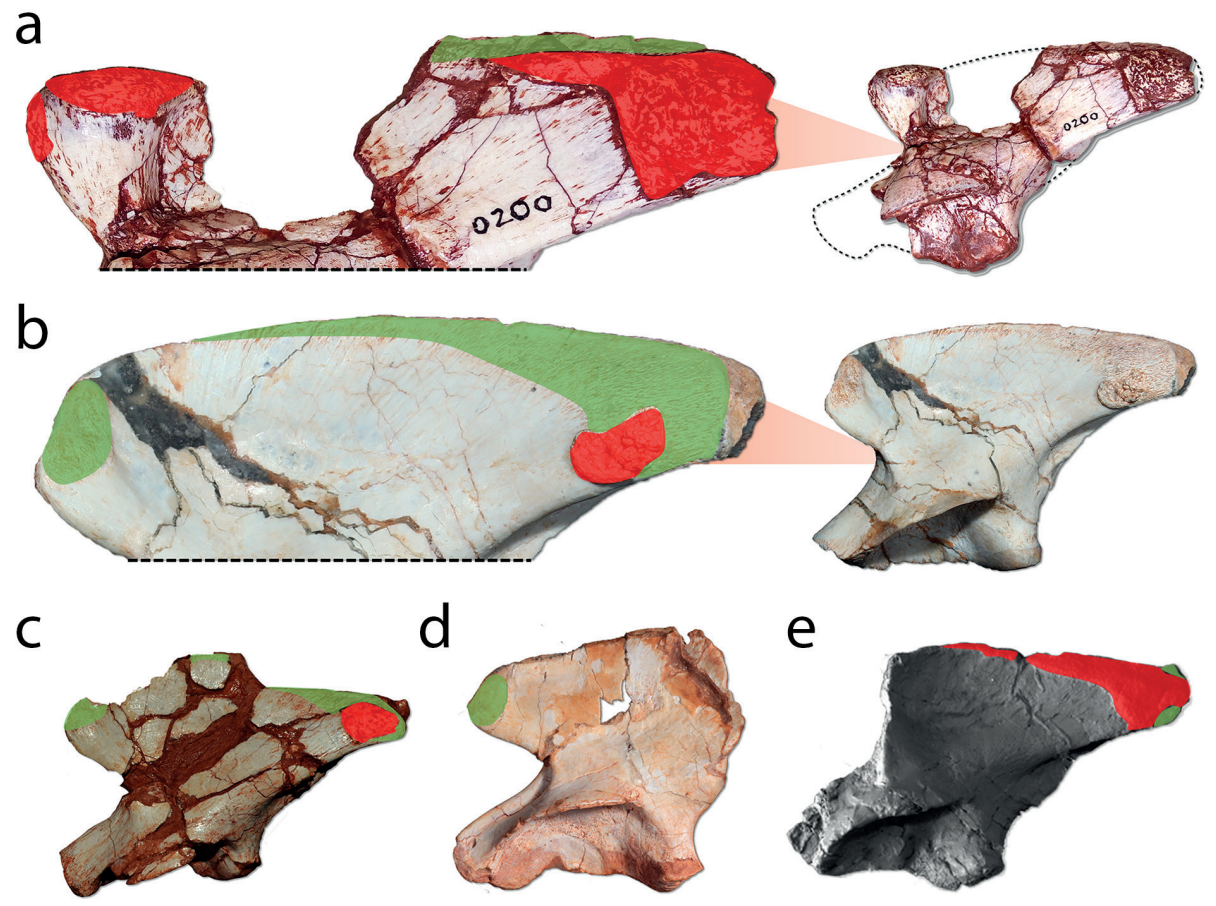

$\mathrm{f}$

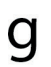

$\mathrm{h}$
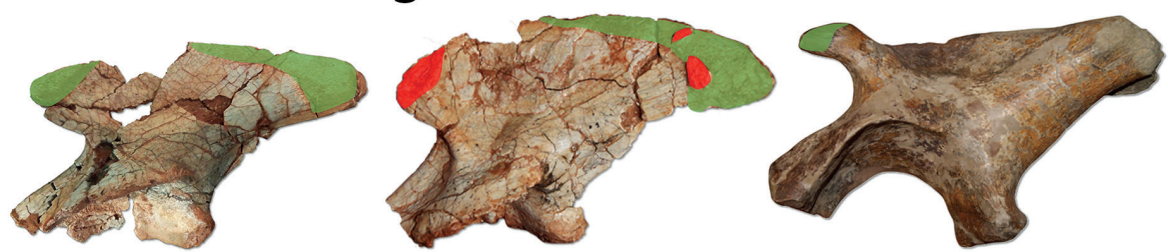

i
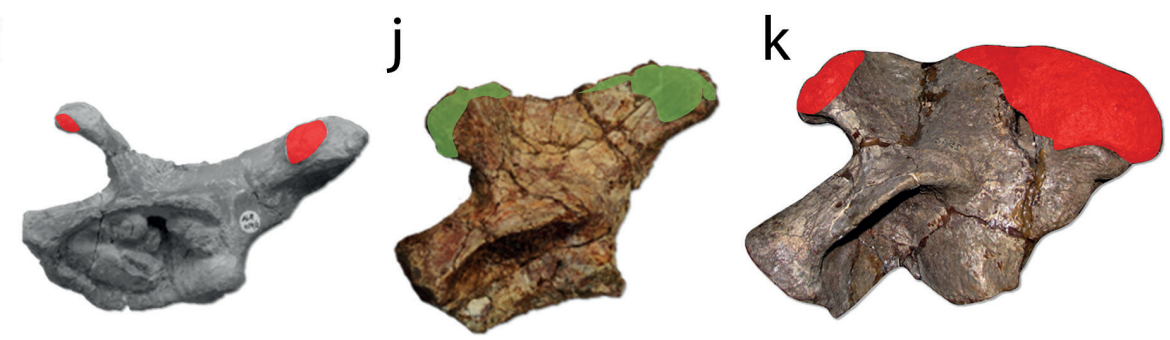

Figure 3 - Selection of dinosauriform ilia and highlight of the muscle scars on the pre and postacetabular alae and on the iliac blade (rugosities and striations). a, CAPPA/UFSM 0200 in lateral view; b, left ilium of Buriolestes schultzi (ULBRA-PVT280) in lateral view; c, left ilium of Buriolestes schultzi (ULBRA-PVT280) in lateral view; d, left ilium of Pampadromaeus barberenai (ULBRAPVT016) in lateral view; e, right ilium of Chromogisaurus novasi (PVSJ 845) in lateral view (reversed), modified from Martínez et al. 2013; f, right ilium of Saturnalia tupiniquim (MCP 3946-PV) in lateral view (reversed), modified from Bittencourt et al. 2012; g, left ilium of Saturnalia tupiniquim (MCP 3945-PV) in lateral view; h, right ilium of Plateosaurus (SMNS 12250) in lateral view (reversed), modified from Bittencourt et al. 2012; i, left ilium of Silesaurus opolensis (ZPAL AbIII404/1) in lateral view, modified from Peecook et al. 2013; j, left ilium of Lutungutali sitwensis (NHCC LB32); k, right ilium of Herrerasaurus ischigualastensis (PVL 2566) in lateral view (reversed), modified from Bittencourt et al. 2012. Specimens not to scale. Muscle scars marked in green are striations and in red are rugosities. 
The medial surface of CAPPA/UFSM 0200 bears a series of scars and marks for the articulation of the two primordial sacral vertebrae. Additionally, the long postacetabular ala suggests the presence of a caudosacral vertebra, a condition that matches basal saurischian dinosaurs (Novas 1996, Langer and Benton 2006). In addition, and as in Chromogisaurus novasi, the scar for the articulation of the first primordial sacral rib/ transverse process molds an "inverted C" shape on the medial surface of the left ilium on its midcranial portion (Fig. 2b, 2d). Likewise, the scar of the second primordial sacral rib is located at the middle portion of the ilium (Fig. 2b, 2d). The caudalmost area of the postacetabular ala bears scars and a "gap" suggesting the presence of a third sacral vertebra (i.e. caudosacral) (Fig. 2b, 2d), similar to the condition encountered in most coeval sauropodomorphs and Thecodontosaurus antiquus. Conversely, Saturnalia tupiniquim (MCP-3845 PV) presents a dorsal vertebra incorporated to the sacral series (i.e. dorsosacral) (see Marsola et al. 2019), similar to Riojasaurus incertus.

The postacetabular ala of CAPPA/UFSM 0200 is slightly more robust than that of coeval basal saurischian dinosaurs (e.g. Buriolestes schultzi, Panphagia protos) excepting herrerasaurids, resembling the condition present in Chromogisaurus novasi, Guaibasaurus candelariensis, and Nhandumirim waldsangae. As in most basal forms, such as Bagualosaurus agudoensis, Buriolestes schultzi, Guaibasaurus candelariensis, Panphagia protos, Saturnalia tupiniquim, and also in nondinosaurian dinosauriforms (Peecook et al. 2013), the postacetabular ala of CAPPA/UFSM 0200 is caudally elongated, possesses a well-developed brevis shelf which laterodorsally delimits an also well-developed brevis fossa, both acting as attachment areas for the $m$. caudofemoralis brevis (Gatesy 1990, Hutchinson 2001) (Fig. 2a, 2c). In CAPPA/UFSM 0200 the brevis fossa is more ventrally located than in Bagualosaurus agudoensis,
Buriolestes schultzi, Chromogisaurus novasi, and Silesaurus opolensis. As in Buriolestes schultzi and Pampadromaeus barberenai, the shelf itself does not merge cranially with the supraacetabular crest. Caudal to the supraacetabular crest, and dorsal to the ischiadic peduncle, CAPPA/UFSM 0200 bears a small foramen (Fig. 2a, 2c), which we tentatively relate to the innervation of the $m$. caudofemoralis brevis. This foramen is similar to that present in Buriolestes schultzi (ULBRA-PVT280) (Fig. 2a, 2c), Efraasia minor, Nhandumirim waldsangae (which presents two foramina instead of one), and Pampadromaeus barberenai. At the caudalmost portion of the postacetabular ala, CAPPA/UFSM 0200 presents a strong developed rugosity on the lateral side of the ilium (Fig. 2, 3a) that forms a raised surface or protuberance, which is more prominent than that of Asilisaurus kongwe, Caseosaurus crosbyensis, Eoraptor lunensis, Herrerasaurus ischigualastensis, Ignotosaurus fragilis, Lutungutali sitwensis, Silesaurus opolensis, and even Buriolestes schultzi, Chromogisaurus novasi, and Saturnalia tupiniquim (see Discussion) (Fig. 3). The cranial margin of this rough rugosity connects to the extended rugosity area on the dorsal margin of the iliac blade and possibly relates to the attachment for either $m$. flexor tibialis externus or $m$. iliofibularis (Langer 2003, Ezcurra 2010). The medial blade of the postacetabular ala, which extends craniocaudally, is ventromedially developed, forming roughly a right angle with the brevis shelf.

The supraacetabular crest of CAPPA/UFSM 0200 is fragmented on its cranialmost portion, where the pubic peduncle would be located (Fig. 2a, 2c). As in Buriolestes schultzi, Chromogisaurus novasi, and Panphagia protos the supracetabular crest extends lateroventrally, forming the acetabular roof, and its lateralmost extension is located slightly caudal to the ischiadic peduncle. In CAPPA/UFSM 0200, the supraacetabular crest extends ventrolaterally, forming an angle of 
$65^{\circ}$ relative to the acetabular wall and partially covering the acetabulum. This character state is present in neotheropods, such as Coelophysis, Dilophosaurus, Liliensternus, Ceratosaurus, and Eoabelisaurus (Langer et al. 2017). However, in CAPPA/UFSM 0200 it is difficult to determine if this is either a taphonomic artifact (Müller et al. 2018b) or a unique trait among coeval taxa, because the bone surface is crushed right above the supraacetabular crest. The acetabulum is roughly as lateromedially deep as craniocaudally long, differing from Nhandumirim waldsangae, and the acetabular wall is lateromedially compressed on its cranial portion. Additionally, its preserved ventral margin is mostly straight, but with a faint concavity, approaching the condition observed in Chromogisaurus novasi and Pampadromaeus barberenai, and contrasting with Bagualosaurus agudoensis, Buriolestes schultzi, and Saturnalia tupiniquim, as these possess an almost straight ventral margin, although these differences may be due to taphonomic and preservational processes (Müller et al. 2018b). As in most basal saurischian dinosaurs, the ischiadic peduncle extends ventrocaudally, and its articular surface is ovoid in cross section, the convex cranioventral surface, which corresponds to the antitrochanter (Langer et al. 2011), merges cranially with the acetabulum wall. In addition, the antitrochanter of CAPPA/UFSM 0200 does not present a raised process (Fig. 2), as in Guaibasaurus candelariensis and Ixalerpeton polesinensis. In the homologous area of the antitrochanter of CAPPA/UFSM 0200, however it is indeed possible to observe a slight variation on the texture of the bone surface as in Guaibasaurus candelariensis (Langer et al. 2011).

\section{PHYLOGENETIC ANALYSIS}

CAPPA/UFSM 0200 was scored in three different morphological datasets in order to test its phylogenetic affinities: Cabreira et al. (2016),
Martínez et al. (2013), and Langer et al. (2017). These datasets reflect distinct evolutionary hypotheses, although they are based upon almost the same sample of taxa coeval with CAPPA/ UFSM 0200. Accordingly, besides CAPPA/UFSM 0200, we also included Buriolestes schultzi (based on the holotype: ULBRA-PVT280) in the dataset by Martínez et al. (2013) and Chromogisaurus novasi (PVSJ 845) in the dataset by Langer et al. (2017). Regardless of the fragmentary condition of Chromogisaurus novasi, we included it in the dataset primarily due to its taxonomic significance within Saturnaliinae (Ezcurra, 2010). We excluded Agnosphitys cromhallensis from the analyses by Martínez et al. (2013) and Langer et al. (2017) because of its fragmentary condition. Besides, we also added character 362 of the dataset adopted by Martínez et al. (2013) into the dataset of Cabreira et al. (2016) (as character 257) and performed both analyses with and without this new character. This character focus on the presence or absence of strong rugosities on the posterior portion of the postacetabular process of the ilium, which are related to the attachment of $m m$. flexor tibialis and iliotibialis. The datasets were processed with the software TNT v1.5 (Goloboff et al. 2008). Additive (i.e. ordered) characters were treated as in the original datasets, and all (ordered and unordered) received the same weight. Euparkeria capensis was used to root the most parsimonious trees (MPTs) and they all were recovered via "traditional search" [random addition sequence + tree bisection reconnection (TBR)], with 5000 replicates of Wagner trees (random seed $=0$ ), TBR and branch swapping, saving 20 trees save per replicate. See Appendix for the codification of CAPA/UFSM 0200 in the used datasets and codification for the added character. 


\section{RESULTS}

In the first analysis using the dataset of Cabreira et al. (2016) (Fig. 4a), we recovered 432 MPTs of 846 steps each [CI (consistency index $)=0.348$, RI (retention index $)=0.637, \mathrm{RC}$ (rescaled consistency index $)=0.221]$, and the strict consensus tree places CAPPA/UFSM 0200 in a polytomy within saurischian dinosaurs, as neither a sauropodomorph nor a theropod. The second analysis employing this dataset (Fig. 4b), which included character 257, recovered 54 MPTs of 848 steps $(\mathrm{CI}=0.348$, RI $=0.638, \mathrm{RC}=0.222)$, and CAPPA/UFSM 0200 was nested as a saturnaliin sauropodomorph in all trees. The strict consensus tree recovered CAPPA/ UFSM 0200 in a sister group relationship with Saturnalia tupiniquim, with Chromogisaurus novasi recovered as the sister taxon to this clade. As defined by Ezcurra (2010), Saturnaliinae includes Chromogisaurus novasi, Saturnalia tupiniquim, their last common ancestor and all its descendants. The only character supporting the clade CAPPA/UFSM $0200+$ Saturnalia tupiniquim is the iliac blade depth relative to the acetabulum being twice deeper or more [249 (1)]. Among the synapomorphies that support Saturnaliinae in this analysis, CAPPA/UFSM 0200 only presents a strong trapezoidal rugosity that extends over the caudal portion of the postacetabular process [257 (1)]. It is important to point out that this last character is the one included in the second analysis using this dataset.

The analysis with the dataset of Martínez et al. (2013) (Fig. 4c) recovered 630 MPTs of 1230 steps each $(\mathrm{CI}=0.367, \mathrm{RI}=0.691, \mathrm{RC}=0.253)$, with CAPPA/UFSM 0200 nested in a polytomy including early-diverging sauropodomorphs from the Carnian of South America (e.g. Eoraptor lunensis and Saturnalia tupiniquim) and a clade with post-Carnian sauropodomorphs (e.g. Plateosaurus and Thecodontosaurus antiquus). In the strict consensus tree, only one of the 18 character states supporting this arrangement is scored for CAPPA/ UFSM 0200: strongly laterally curved iliac blade in dorsal view, with a deep concave lateral border [372(1)].

Finally, in the analysis employing the dataset of Langer et al. (2017) (Fig. 4d), we recovered 443520 MPTs of 1927 steps each $(\mathrm{CI}=0.273$, RI $=0.619, \mathrm{RC}=0.168) . \mathrm{CAPPA} / \mathrm{UFSM} 0200$ nests within Saturnaliinae in all trees in an unresolved arrangement, which also includes Buriolestes schultzi, Chromogisaurus novasi, Pampadromaeus barberenai, Saturnalia tupiniquim, and Panphagia protos. Curiously, Eoraptor lunensis was recovered outside this clade. Among the 10 synapomorphies supporting Saturnaliinae, only two are scored for CAPPA/UFSM 0200: straight ventral margin of the acetabular wall of the ilium [306 (1)], and presence of rugosity areas on the dorsal and lateral surfaces of the preacetabular and the postacetabular processes of the ilium [318 (1)].

\section{DISCUSSION}

The discovery of CAPPA/UFSM 0200 increases the record of Carnian dinosauromorphs in southern Brazil,comprising thefirstdinosaurcollected atPiche outcrop, quantitatively improving the distribution of dinosaurian remains within the Hyperodapedon Assemblage Zone of the Candelária Sequence. Outcrops of this fossiliferous unit and their correlates in the Ischigualasto Formation (northwestern Argentina) include a dinosauromorph fauna that, so far, comprises lagerpetids (Sereno and Arcucci 1994, Martínez et al. 2013, Cabreira et al. 2016, Garcia et al. 2019), silesaurids (Martínez et al. 2013, see also Agnolin and Rozadilla 2017, Baron 2017), putative ornithischians (Casamiquela 1967, but see Agnolin and Rozadilla 2017, Baron 2017), putative theropods (Martínez et al. 2011, Marsola et al. 2019), and other saurischians, especially herrerasaurids (Reig 1963, Colbert 1970, Alcober and Martínez 2010) and sauropodomorphs 

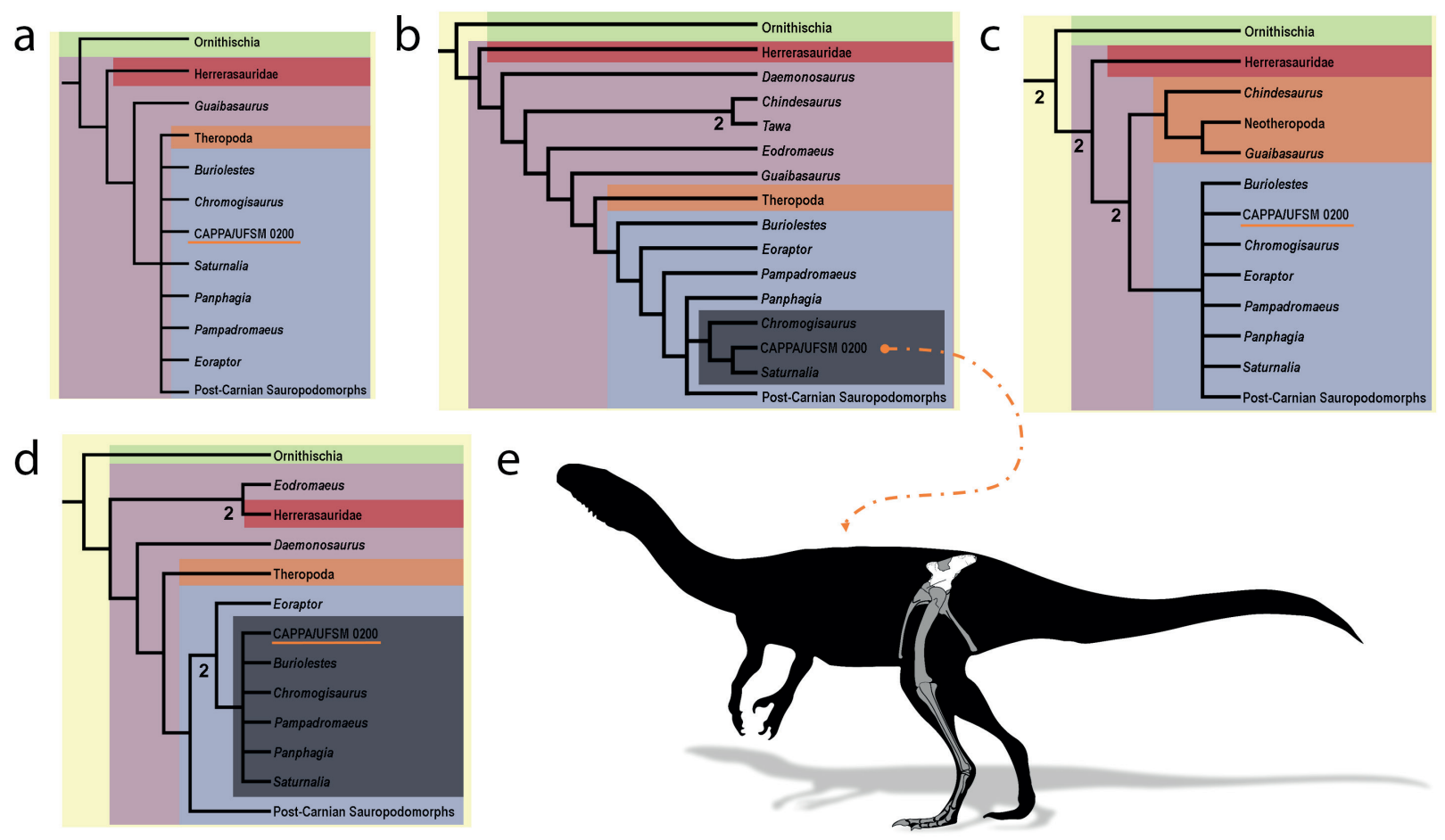

Figure 4 - Phylogenetic affinities of CAPPA/UFSM 0200, reduced strict consensus trees. a, Analysis employing the dataset by Cabreira et al. 2016; b, Analysis employing the dataset by Cabreira et al. 2016 (modified); c, Analysis employing the dataset by Martínez et al. 2013 (modified); d, Analysis employing the dataset by Langer et al. 2017 (modified); e, silhouette presenting a hypothesized hindlimb and pelvic girdle reconstruction to CAPPA/UFSM 0200. Purple box, Saurischia; Orange box, Theropoda; Light Blue box, Sauropodomorpha; Dark Blue box, Saturnaliinae. Numbers represent Bremer support values above 1.

(Eoraptor lunensis Sereno et al. 1993, Saturnalia tupiniquim Langer et al. 1999, Panphagia protos Martínez and Alcober 2009, Chromogisaurus novasi Ezcurra 2010, Pampadromaeus barberenai Cabreira et al. 2011, Buriolestes schultzi Cabreira et al. 2016, Müller et al. 2018a, Bagualosaurus agudoensis Pretto et al. 2018).

Beyond that, CAPPA/UFSM 0200 possesses the usual traits of Carnian saurischian dinosaurs (e.g. postacetabular ala more developed than the preacetabular ala; elongated postacetabular ala; partially perforated acetabulum) and it is mostly similar to early-diverging sauropodomorphs as Buriolestes schultzi, Chromogisaurus novasi, and Saturnalia tupiniquim. In fact, CAPPA/UFSM 0200 is consistently recovered as a saurischian dinosaur in the phylogenetic analyses herein presented and as a saturnaliin sauropodomorph in some of the analyses (Fig. 4). Although CAPPA/UFSM 0200 is morphologically different from Saturnalia tupiniquim, they share the same character states for the ilium in all datasets. Nonetheless, it is relevant to mention that CAPPA/UFSM 0200 is not complete and lacks $40 \%$ of the character states for the ilium. Moreover, the morphology of CAPPA/UFSM 0200 also differs from other coeval taxa mainly by the following combination of traits: concavity on the iliac blade, which is lateromedially deeper than in coeval sauropodomorphs; preacetabular ala that is shorter than in coeval sauropodomorphs; presence of strong developed rugosities on the pre- and postacetabular alae. Individually, similar traits occur in several saurischian dinosaurs (especially in early sauropodomorphs), but in CAPPA/UFSM 0200 their combination is unique. For instance, while Buriolestes schultzi also 
has a short preacetabular ala relatively to other Carnian sauropodomorphs (e.g. Pampadromaeus barberenai; Saturnalia tupiniquim), CAPPA/ UFSM 0200 has a shorter preacetabular ala than Buriolestes schultzi. Another example relies in the lateral concavity, which is lateromedially deeper in Chromogisaurus novasi and Saturnalia tupiniquim, but in CAPPA/UFSM 0200 is even deeper than in those taxa. Consequently, CAPPA/UFSM 0200 may either belong to a new, still unknown taxon from the Candelária Sequence or to an ontogenetically advanced individual belonging to a previously known taxon (see further discussion below), because the aforementioned traits are under the acceptable range of individual variation (i.e. ontogeny, sexual dimorphism).

One of the most conspicuous traits of the specimen relies on the strongly developed rugosities in its pre- and postacetabular alae, extending to the iliac blade, and these may be an artifact of ontogeny (see further discussion below). Although some coeval dinosauriforms do show similar rugosities (Langer 2003, Ezcurra 2010, Cabreira et al. 2016, Müller et al. 2018a), they are fainter than in CAPPA/UFSM 0200. It is important to point out that different specimens of Buriolestes schultzi present variable conditions regarding this trait (Fig. 5), though neither of the specimens reach the robustness of CAPPA/UFSM 0200. The holotype of Buriolestes schultzi (ULBRAPVT280) and a referred specimen (CAPPA/UFSM 0035) both possess rugosities on these areas, whereas ULBRA-PVT056 (a putative juvenile individual) does not present the same condition. To a certain extent, such variation is also observed in distinct specimens of Saturnalia tupiniquim, while MCP 3944-PV and MCP 3945-PV present conspicuous rugosities, MCP 3846-PV does not present the same condition.

A similar condition regarding the iliac rugosities is observed in silesaurids and herrerasaurids such as Asilisaurus kongwe, Caseosaurus crosbyensis,
Herrerasaurus ischigualastensis, Ignotosaurus fragilis, Lutungutali sitwensis, and Silesaurus opolensis, although with slight differences regarding sauropodomorphs as Buriolestes schultzi, Chromogisaurus novasi, and Saturnalia tupiniquim. In silesaurids, sauropodomorphs and Caseosaurus crosbyensis the rugosities appear to be as not extensive as in Herrerasaurus ischigualastensis, in which these rugosities provide a "bulbous" aspect to the ilium in lateral view, although this might be a taphonomic artifact. Baron and Williams (2018) also mention the occurrence of rugosities in the ilia of Coelophysis bauri and Staurikosaurus pricei. Although, the homology of these rugosities is difficult to determine in dinosauromorphs (Baron and Williams 2018), at least in sauropodomorphs they seem to be restricted to the early-diverging forms, because Bagualosaurus agudoensis, Efraasia minor, Melanorosaurus, Pantydraco caducus, Plateosaurus, Riojasaurus incertus, Thecodontosaurus antiquus and other post-Carnian sauropodomorphs (McPhee and Choiniere 2016) seem to not present them, or to only present faint scars in the homologous area. Nonetheless, we could not observe either condition in Panphagia protos because the dorsal portion (most of the iliac blade) of the holotype's ilium is fragmented, whereas the preserved portion of the ilium (roughly the cranialmost half) of Pampadromaeus barberenai does not exhibit the rugosities on its preacetabular ala, and neither does Eoraptor lunensis. Moreover, since the strong developed rugosity is regarded as one of the key characters supporting Saturnaliinae (Ezcurra 2010, Martínez et al. 2013), it is essential to consider if this is in fact a reliable taxonomic character or whether it may be result of intraspecific variation (e.g. ontogeny, sexual dimorphism, and individual variation). Actually, several studies demonstrated that variation play a significant role in the presence, absence, and morphology of several traits extensively applied in phylogenetic studies of dinosauromorphs (Nesbitt et al. 2009, 


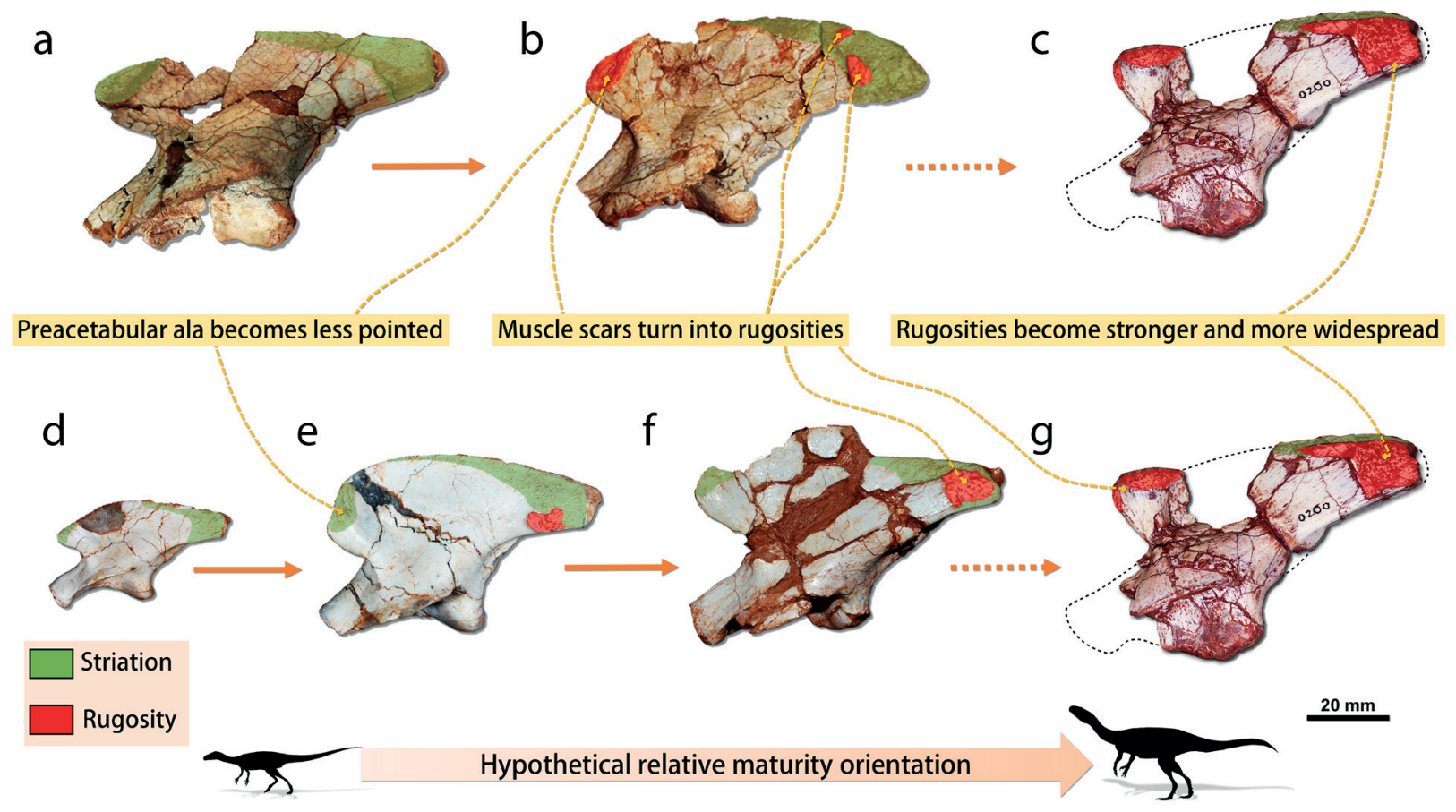

Figure 5 - Hypothetical ontogenetic model to Saturnalia tupiniquim (above) and Buriolestes schultzi (below) based on the iliac muscle scars and morphology. Specimens placed from the "least mature" to the "most mature" from left to right. a, Saturnalia tupiniquim (MCP 3946-PV); b, Saturnalia tupiniquim (MCP 3945-PV); c, hypothetical ontogenetic advanced individual of Saturnalia tupiniquim (CAPPA/UFSM 0200); d, Buriolestes schultzi (putative juvenile specimen ULBRA-PVT056); e, Buriolestes schultzi (ULBRA-PVT280); f, Buriolestes schultzi (CAPPA/UFSM 0035); g, hypothetical ontogenetic advanced individual of Buriolestes schultzi (CAPPA/UFSM 0200). Specimens under scale.

Piechowski et al. 2014, 2018, Griffin and Nesbitt 2016a, b, Müller et al. 2017a).

While an extensive analysis on the ontogeny of sauropodomorphs is beyond the scope of this paper, we list and describe some possible ontogenetic trends that are observable in specimens of Buriolestes schultzi and Saturnalia tupiniquim, including CAPPA/UFSM 0200 as a potential model for an ontogenetically advanced individual of both taxa. Following our hypothetical orientation of relative maturity in Figure 5, there is a trend though ontogeny in both the ilium of Buriolestes schultzi and Saturnalia tupiniquim of a shortening of the preacetabular ala (i.e. it becomes more rounded and/or subquadrangular and less pointed) and of the development of strong rugosities in the muscle scars present in both alae. This may be an indication that these muscle scars could reveal the relative maturity of the specimens, however without histological analyses and a broader ontogenetic approach, such assumption still remains ambiguous. Regarding Saturnalia tupiniquim, it is also noticeable that the lateral concavity of the ilium becomes deeper as the specimens are more ontogenetic advanced. In this case, the size of the specimens does not directly reflect the relative maturity, once all three (MCP 3946-PV; MCP 3945-PV; CAPPA/UFSM 0200) are similar in size, although they present different conditions in the traits previously cited. On the other hand, Buriolestes schultzi preserves a more complete ontogenetic series, presenting a putative juvenile specimen (ULBRA-PVT056; see also Müller and Garcia 2019), which will be formally described elsewhere. As in MCP 3946-PV, which is herein used as the less mature specimen of Saturnalia tupiniquim, and Pantydraco caducus, 
ULBRA-PVT056 has a pointed preacetabular ala. Its muscle scars are faint striations along both alae, and overall it is proportionally more elongated than ULBRA-PVT280, CAPPA/UFSM 0035 and CAPPA/UFSM 0200.

Because ontogenetic data of most Triassic dinosauromorphs are scarce, and many taxa are restricted to a single incomplete specimen (e.g. Colbert 1970, Martínez and Alcober 2009, Ezcurra 2010, Pretto et al. 2018, Marsola et al. 2019) the limited sample precludes the establishment of a reliable pattern to be followed as a model, whether regarding either ontogeny or individual variation. Once such traits could be related to intraspecific variation, we suggest caution when considering the faintness or roughness (i.e. the degrees of "development") of these muscle scars in phylogenetic or taxonomic evaluations. The inclusion of the character regarding "strong trapezoidal rugosity that extends over the caudal portion of the postacetabular process of the ilium" modified the topologies recovered in Cabreira et al. (2016), nesting CAPPA/UFSM 0200 with Chromogisaurus novasi and Saturnalia tupiniquim as a saturnaliin sauropodomorph, which suggests that this character (even though it is not the only character supporting Saturnaliinae) might actually result from ontogenetic variation, and, accordingly, would be reliable only for mature individuals. However, it is important to note that Buriolestes schultzi (ULBRAPVT280, CAPPA/UFSM 0035) also presents a rugosity in the postacetabular process of the ilium, but as it is less developed and more restricted than in saturnaliin sauropodomorphs, it was coded differently (this is also true for silesaurids and Herrerasaurus ischigualastensis). In summary, based upon carefully examination of several ilia of different early dinosaurs and dinosauromorphs, it is remarkable that muscle scars and/or rugosities are very variable between specimens of the same taxon (e.g. Buriolestes schultzi; Saturnalia tupiniquim). It is not clear if these variations result from ontogeny, sexual dimorphism or any other type of intraspecific variation, which makes a character based on this trait unstable and subjective. Nevertheless, the rugosities most likely present a phylogenetic signal, as they are absent in more advanced sauropodomorphs (e.g. Adeopapposaurus mognai Martínez 2009; Plateosaurus), which could indicate some heterochronical pattern, where even mature individuals possess the condition once present in juvenile early-diverging sauropodomorphs (i.e. absence of rugosities). Indeed, this seems a pedomorphic trait that could be related to the absence of a trochanteric shelf in the femora of all ontogenetic stages of mature individuals of postCarnian sauropodomorphs. On the other hand, the trochanteric shelf comprises a muscle attachment absent in immature individuals, but present and well-developed in more mature individuals of Carnian sauropodomorphs (e.g. Buriolestes schultzi; Saturnalia tupiniquim; Nesbitt 2011, Müller et al. 2018a; see also Müller and Garcia 2019), for instance. Therefore, the rugosities seem to work well in a broad phylogenetic context, but should be carefully considered at alpha taxonomic level.

\section{CONCLUSIONS}

The specimen herein described increases the dinosauromorph record for the Carnian from southern Brazil and represents the first dinosaur record from the Piche outcrop, which along with other sites from São João do Polêsine, Rio Grande do Sul State, comprises one of the oldest dinosaurbearing units worldwide. CAPPA/UFSM 0200 presents some differences in comparison to coeval dinosaurs, and all the phylogenetic analyses herein performed consistently recovered CAPPA/UFSM 0200 as a saurischian dinosaur and potentially a saturnaliin sauropodomorph. Its incompleteness, however, prevents its nesting within a less-inclusive group. One of the character states (the presence 
of the abovementioned iliac rugosities) shared between CAPPA/UFSM 0200 and other saturnaliin sauropodomorphs might actually be result of intraspecific variation, such as ontogeny. Possible ontogenetic trends in the ilia of early-diverging sauropodomorphs show that these rugosities seem to have an ontogenetic signal, although histological analyses would be necessary to confirm maturity of the studied specimens. Finally, an increased sample of specimens is necessary to build a reliable ontogenetic series and improve the knowledge of comparative skeletal anatomy of these animals, and along with anatomical refinement, this would consequently shed light on the alpha taxonomy of early dinosaurs, a mandatory work to compile more reliable phylogenetic data on this fascinating group.

\section{ACKNOWLEDGMENTS}

We are grateful to the Guarienti family, who granted access to their property during the collection of the specimen. We thank Max Langer (LPRP/USP) for allowing access to specimens under his care and for useful suggestions on an earlier version of this project. We extend our gratitude to Amanda Brum (UFSM) and Julio Marsola (LPRP/USP) for helpful discussions and comments, and to Mateusz Talanda (University of Warsaw, Poland) for providing detailed photographs of Silesaurus opolensis. We highly appreciate the reviews and comments provided by the Associate Editor and both the reviewers Christopher Griffin and Federico Agnolin, which greatly improved the quality of the manuscript. This work was supported by a Fundação de Amparo à Pesquisa do Estado do Rio Grande do Sul (FAPERGS) scholarship to MSG and by Conselho Nacional de Desenvolvimento Científco e Tecnológico [CNPq; research grant to SDS, process number 306352/2016-8]. We also extend our gratitude to the Willi Hennig Society, for the free use of TNT software.

\section{AUTHOR CONTRIBUTIONS}

MSG and RTM designed the study; FAP and RTM performed collection and preparation of the specimen; MSG, FAP, and RTM performed the analyses; MSG, FAP, SDS, and RTM discussed the results; MSG, FAP, SDS, and RTM wrote the article.

\section{REFERENCES}

AGNOLIN FL AND ROZADILLA S. 2017. Phylogenetic reassessment of Pisanosaurus mertii Casamiquela, 1967, a basal dinosauriform from the Late Triassic of Argentina. J Syst Palaeontol: 1-27.

ALCOBER OA AND MARTÍNEZ RN. 2010. A new herrerasaurid (Dinosauria, Saurischia from the Upper Triassic Ischigualasto Formation of northwestern Argentina. ZooKeys 63: 55-81.

ANDREIS RR, BOSSI GE AND MONTARDO DK. 1980. O Grupo Rosário do Sul (Triássico) no Rio Grande do Sul. In: Congresso Brasileiro de Geologia 31: 659-673.

BARON MG. 2017. Pisanosaurus mertii and the Triassic ornithischian crisis: could phylogeny offer a solution? Historical Biology: An Inter J Paleo: DOI 10.1080/08912963.2017.1410705.

BARON MG AND WILLIAMS ME. 2018. A re-evaluation of the enigmatic dinosauriform Caseosaurus crosbyensis from the Late Triassic of Texas, USA and its implications for early dinosaur evolution. Acta Palaeontol Pol 63(1): 129-145.

BENTON MJ, JULL L, STORRS GW AND GALTON PM. 2000. Anatomy and systematics of the prosauropod dinosaur Thecodontosaurus antiquus from the upper Triassic of southwestern England. J Vert Paleontol 20:77108.

BITTENCOURT JS AND KELLNER AWA. 2009. The anatomy and phylogenetic position of the Triassic dinosaur Staurikosaurus pricei Colbert, 1970. Zootaxa 2079: 1-56.

BITTENCOURT JS, LEAL LA, LANGER MC AND AZEVEDO SAK. 2012. An additional basal sauropodomorph specimen from the Upper Triassic Caturrita Formation, southern Brazil, with comments on the biogeography of plateosaurids. Alcheringa 36(2): 269278.

BONAPARTE JF, FERIGOLO J AND RIBEIRO AM. 1999. A new early late Triassic saurischian dinosaur from Rio Grande do Sul state, Brazil. National Science Museum Monographs 15: 89-109.

CABREIRA SF ET AL. 2016. A unique Late Triassic dinosauromorph assemblage reveals dinosaur ancestral anatomy and diet. Curr Biol 26: 3090-3095. 
CABREIRA SF, SCHULTZ CL, BITTENCOURT JS, SOARES MB, FORTIER DC, SILVA LR AND LANGER MC. 2011. New stem-sauropodomorph (Dinosauria, Saurischia) from the Triassic of Brazil. Naturwissenschaften 98: 1035-1046.

CASAMIQUELA RM. 1967. Un nuevo dinosaurio ornitisquio Triásico (Pisanosaurus mertii: Ornithopoda) de la Formación Ischigualasto, Argentina. Ameghiniana 4: 4764.

COLBERT EH. 1970. A saurischian dinosaur from the Triassic of Brazil. Am Mus Novit 2405: 1-60.

DA SILVA RC, BARBONI R, DUTRA T, GODOY MM, BINOTTO RB. 2012. Footprints of large theropod dinosaurs and implications on the age of Triassic biotas from southern Brazil. J S Am Earth Sci 39: 16-23.

DA SILVA RC, CARVALHO IS AND FERNANDES ACS. 2008. Pegadas de dinossauros do Triássico (Formação Santa Maria) do Brasil. Ameghiniana 45(4): 783-790.

DZIK J. 2003. A Beaked Herbivorous Archosaur with Dinosaur Affinities from the Early Late Triassic of Poland. J Vert Paleontol 23(3): 556-574

EZCURRA MD. 2010: A new early dinosaur (Saurischia: Sauropodomorpha) from the Late Triassic of Argentina: a reassessment of dinosaur origin and phylogeny. J Syst Palaeontol 8: 371-425.

EZCURRA MD. 2016. The phylogenetic relationships of basal archosauromorphs, with an emphasis on the systematics of proterosuchian archosauriforms. PeerJ 4: e1778.

FERIGOLO J AND LANGER MC. 2007. A Late Triassic dinosauriform from South Brazil and the origin of the ornithischian predentary bone. Historical Biology: An Inter J Paleo: 1-11.

GARCIA MS, MÜLLER RT, DA-ROSA ÁAS AND DIASDA-SILVA S. 2019. The oldest known co-occurrence of dinosaurs and their closest relatives: a new lagerpetid from a Carnian (Upper Triassic) bed of Brazil with implications for dinosauromorph biostratigraphy, early diversification and biogeography. J S Am Earth Sci 91: 302-319.

GATESY SM. 1990. Caudofemoral musculature and the evolution of theropods locomotion. Paleobiology 16: 170186.

GOLOBOFF PA, FARRIS JS, NIXON AND KCC. 2008. TNT, a free program for phylogenetic analysis. Cladistics 24: 774-786.

GRIFFIN CT AND NESBITT SJ. 2016a. Anomalously high variation in postnatal development is ancestral for dinosaurs but lost in birds. PNAS 113(51): 14757-14762.

GRIFFIN CT AND NESBITT SJ. 2016b. The femoral ontogeny and long bone histology of the Middle Triassic (Late Anisian) dinosauriform Asilisaurus kongwe and implications for the growth of early dinosaurs. J Vert Paleontol 36: e1111224.

HORN BLD, MELO TM, SCHULTZ CL, PHILIPP RP, KLOSS HP AND GOLDBERG K. 2014. A new third- order sequence stratigraphic framework applied to the Triassic of the Paraná Basin, Rio Grande do Sul, Brazil, based on structural, stratigraphic and paleontological data. J S Am Earth Sci 55: 123-132.

HUENE FVON. 1932. Die fossile Reptil-Ordnung Saurischia, ihre Entwicklung und Geschichte. Monographien zur Geologie und Paläontologie 4: 1-361.

HUNT AP, LUCAS SG, HECKERT AB, SULLIVA R.M AND LOCKLEY MG. 1998. Late Triassic dinosaurs from the western United States. Géobios 31: 511-531.

HUTCHINSON J. 2001. The evolution of pelvic osteology and soft tissues on the line to extant birds (neornithes). Zool J Linn Soc 131(2): 123-168.

JENISCH AG, LEHN I, GALLEGO OF, MONFERRAN MD, HORODYSKI RS AND FACCINI UF. 2017. Stratigraphic distribution, taphonomy and paleoenvironments of Spinicaudata in the Triassic and Jurassic of the Paraná Basin. J S Am Earth Sci 80: 569-588.

LANGER MC. 2003. The sacral and pelvic anatomy of the stem-sauropodomorph Saturnalia tupiniquim (Late Triassic, Brazil). PaleoBios 23: 1-40.

LANGER MC, ABDALA F, RICHTER M AND BENTON MJ. 1999. A sauropodomorph dinosaur from the Upper Triassic (Carnian) of southern Brazil. Comptes Rendus de l'Academie des Sciences IIA 329: 511-517.

LANGER MC AND BENTON MJ. 2006. Early dinosaurs: a phylogenetic study. J Syst Palaeontol 4(4): 309-358.

LANGER MC, BITTENCOURT JS AND SCHULTZ CL. 2011. A reassessment of the basal dinosaur Guaibasaurus candelariensis, from the Late Triassic Caturrita Formation of south Brazil. Earth Env Sci T R So 101: 301-332.

LANGER MC, EZCURRA MD, BITTENCOURT JS AND NOVAS FE. 2010. The origin and early evolution of dinosaurs. Biol Rev 85: 55-110.

LANGER MC, EZCURRA MD, RAUHUT OWM, BENTON MJ, KNOLL F, MCPHEE BW, NOVAS FE, POL D AND BRUSATTE SL. 2017. Untangling the dinosaur family tree. Nature 551: E1-E3.

LANGER MC, RAMEZANI J AND DA-ROSA ÁAS. 2018. $\mathrm{UPb}$ age constraints on dinosaur rise from south Brazil. Gondwana Res 57: 133-140.

LANGER MC, RIBEIRO AM, SCHULTZ CL AND FERIGOLO J. 2007. The continental tetrapod-bearing Triassic of South Brazil. New Mexico Mus Nat Hist Sci Bull 41: 201-218.

MARSOLA JCA, BITTENCOURT JS, BUTLER RJ, DAROSA ÁAS, SAYÃO JM AND LANGER MC. 2019. A new small-bodied dinosaur with theropod affinities from the Late Triassic Santa Maria Formation, South Brazil. J Vert Paleontol 38(5): e1531878.

MARTÍNEZ RN. 2009. Adeopapposaurus mognai, gen. et sp. nov. (Dinosauria: Sauropodomorpha), with comments on 
adaptations of basal sauropodomorpha. J Vert Paleontol 29(1): 142-164.

MARTÍNEZ RN AND ALCOBER OA. 2009. A basal sauropodomorph (Dinosauria: Saurischia) from the Ischigualasto Formation (Triassic, Carnian) and the early evolution of Sauropodomorpha. PLoS One 4 (2): e4397.

MARTÍNEZ RN, APALDETTIC, ALCOBER OA, COLOMBI CE, SERENO PC, FERNANDEZ E, SANTI MALNIS P, CORREA GA AND ABELIN D. 2013. Vertebrate succession in the Ischigualasto Formation. J Vert Paleontol 31: 10-30.

MARTÍNEZ RN, SERENO PC, ALCOBER OA, COLOMBI CE, RENNE PR, MONTAÑEZ IP AND CURRIE BS. 2011. A basal dinosaur from the dawn of the dinosaur era in southwestern Pangaea. Science 331: 201-210.

MCPHEE BW AND CHOINIERE JN. 2016. A hyperrobust sauropodomorph dinosaur ilium from the Upper Triassic-Lower Jurassic Elliot Formation of South Africa: Implications for the functional diversity of basal Sauropodomorpha. J Afr Earth Sci 123: 177e184.

MOSER M. 2003. Plateosaurus engelhardti Meyer, 1837 (Dinosauria: Sauropodomorpha) from the Feuerletten (Mittelkeuper, Upper Triassic) of Bavaria. Zitteliana 24: 3-186.

MÜLLER RT AND GARCIA MS. 2019. Rise of an empire: analysing the high diversity of the earliest sauropodomorph dinosaurs through distinct hypotheses. Historical Biology: An Inter J Paleo: DOI 10.1080/08912963.2019.1587754.

MÜLLER RT, GARCIA MS, DA-ROSA ÁAS AND DIAS-DA-SILVA S. 2018b. Under pressure: Effect of sedimentary compression on the iliac morphology of early sauropodomorphs. J S Am Earth Sci 88: 345-351.

MÜLLER RT, LANGER MC, AIRES, ASS AND DIASDA SILVA S. 2014. New dinosauriform (Ornithodira, Dinosauromorpha) record from the Upper Triassic of southern Brazil. Palentol Res 18(2): 118-121.

MÜLLER RT, LANGER MC, BRONZATI M PACHECO CP, CABREIRA SF AND DIAS-DA-SILVA S. 2018a. Early evolution of sauropodomorphs: anatomy and phylogenetic relationships of a remarkably well preserved dinosaur from the Upper Triassic of southern Brazil. Zool J Linn Soc: 1-62.

MÜLLER RT, LANGER MC, CABREIRA SF AND DIAS-DA-SILVA S. 2015. The femoral anatomy of Pampadromaeus barberenai based on a new specimen from the Upper Triassic of Brazil. Historical Biology: An Inter J Paleo: DOI 10.1080/08912963.2015.1004329.

MÜLLER RT, LANGER MC AND DIAS-DA-SILVA S. 2018c. An exceptionally preserved association of complete dinosaur skeletons reveals the oldest long-necked sauropodomorphs. Biol Letters 14(11): 1744-9561.

MÜLLER RT, LANGER MC, PACHECO CP AND DIASDA-SILVA S. 2017a. The role of ontogeny on character polarization in early dinosaurs: a new specimen from the Late Triassic of southern Brazil and its implications. Historical Biology: An Inter J Paleo: DOI 10.1080/08912963.2017.1395421.

MÜLLER RT, PRETTO FA, STEFANELLO M, SILVANEVES E AND DIAS-DA-SILVA S. 2017b. On a dinosaur axis from one of the oldest dinosaur-bearing sites worldwide. Acta Palaeontol Pol 62(3): 543-548.

NESBITT SJ. 2011. The early evolution of archosaurs: Relationships and the origin of major clades. B Am Mus Nat Hist 352: 1-292.

NESBITT SJ, IRMIS RB, PARKER WG, SMITH ND, TURNER AH AND ROWE T. 2009. Hindlimb osteology and distribution of basal dinosauromorphs from the Late Triassic of North America. J Vert Paleontol 29(2): 498516.

NESBITT SJ, SIDOR CA, IRMIS RB, ANGIELCZYK KD, SMITH RMH AND TSUJI LA. 2010. Ecologically distinct dinosaurian sister group shows early diversification of Ornithodira. Nature 464: 95-98.

NOVA FE. 1994. New Information on the Systematics and Postcranial Skeleton of Herrerasaurus ischigualastensis (Theropoda: Herrerasauridae) from the Ischigualasto Formation (UpperTriassic) of Argentina. J Vert Paleontol 13 (4): 400-423.

NOVAS FE. 1996. Dinosaur monophyly. J Vert Paleontol 16: 723-741.

PEECOOK BR, SIDOR CA, NESBITT SJ, SMITH RMH, STEYER JS AND ANGIELCZYK KD. 2013. A new silesaurid from the upper Ntawere Formation of Zambia (Middle Triassic) demonstrates the rapid diversification of Silesauridae (Avemetatarsalia, Dinosauriformes). J Vert Paleontol 33(5): 1127.

PEREZ PA AND MALABARBA MC. 2002. A Triassic freshwater fish fauna from the Paraná Basin in southern Brazil. Rev Bras Paleontolog 4: 27-33.

PIECHOWSKI R, NIEDŹWIEDZKI G AND TAŁANDA M. 2018. Unexpected birdlike features and high intraspecific variation in the braincase of the Triassic relative of dinosaurs. Historical Biology: An Inter J Paleo: DOI 10.1080/08912963.2017.1418339.

PIECHOWSKI R, TALANDA M AND DZIK J. 2014. Skeletal variation and ontogeny of the Late Triassic Dinosauriform Silesaurus opolensis. J Vert Paleontol 34(6): 1383-1393.

POL D AND POWELL JE. 2007. New information on Lessemsaurus sauropoides (Dinosauria: Sauropodomorpha) from the Upper Triassic of Argentina. Special Papers in Palaeontology 7: 223-243.

PRETTO FA, LANGER MC AND SCHULTZ CL. 2018. A new dinosaur (Saurischia: Sauropodomorpha) from the Late Triassic of Brazil provides insights on the evolution of sauropodomorph body plan. Zool J Linn Soc: 1-29. 
PRETTO FA, SCHULTZ CL AND LANGER MC. 2015. New dinosaur remains from the Late Triassic of southern Brazil (Candelária Sequence, Hyperodapedon Assemblage Zone). Alcheringa: DOI 10.1080/03115518.2015.994114.

REIG OA. 1963. La presencia de dinosaurios saurisquios en los "Estrados de Ischigualasto" (Mesotriasico superior) de las Provincias de San Juan y La Rioja (Republica Argentina). Ameghiniana 3: 3-20.

SERENO PC. 1999. The evolution of dinosaurs. Science 284: 2137-2147.

SERENO PC. 2007. Basal Sauropodomorpha: historical and recent phylogenetic hypotheses, with comments on Ammosaurus major (Marsh, 1889). Special Papers in Palaeontology 77: 261-289.

SERENO PC AND ARCUCCI AB. 1994. Dinosaurian precursors from the Middle Triassic of Argentina: Marasuchus lilloensis, gen. nov. J Vert Paleontol 14: 5373.

SERENO PC, FORSTER CA, ROGERS RR AND MONETTA AM. 1993. Primitive dinosaur skeleton from Argentina and the early evolution of Dinosauria. Nature 361: 64-66.

SERENO PC, MARTÍNEZ RN AND ALCOBER OA. 2013. Osteology of Eoraptor lunensis (Dinosauria, Sauropodomorpha). J Vert Paleontol 32: 83-179.

YATES AM. 2003a. A new species of the primitive dinosaur Thecodontosaurus (Saurischia: Sauropodomorpha) and its implications for the systematics of early dinosaurs. J Syst Palaeontol 1: 1-42.

YATES AM. 2003b. The species taxonomy of the sauropodomorph dinosaurs from the Löwenstein Formation (Norian, Late Triassic) of Germany. Palaeontology 46(2): 317-337.

ZERFASS H, SANDER A AND FLORES AF. 2007. Agudo, Folha SH.22-V.C.V, escala 1:100.000, Rio Grande do Sul. Serviço Geológico do Brasil (CPRM), Brasília.

\section{APPENDIX}

Phylogenetic analyses expanded data. Codification for CAPPA/UFSM 0200 on the dataset by Martínez et al. (2013): ????????????????????? ?????????????????????????????????????????? ????????????????????????????????????????????? ????????????????????????????????????????????? ????????????????????????????????????????????? ??????????????????????????????????????????000 0011?0??20??????????????????????????????????? ????????????????????????????????????????????? ????????????????????????1????????11??????
Codification for Buriolestes schultzi on the dataset by Martínez et al. (2013): 00?10?0[12]10 00101??1?????001???0?1?0?????????????0?10? ???????????001?????????????????????????1000 0010???0?01000000010?00??????????????????? ?????????001??0?????10?00???0????0??010001? 0??0?0??????????0????01100000??????????????? ?????????????????00000111[01]00201?????????? ?11?????1??00001011100010111000000?000?01?

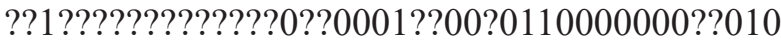
??0???001210?1???11?1????

Codification for CAPPA/UFSM 0200 on the dataset by Cabreira et al. (2016): ???????????????? ??????????????????????????????????????????? ?????????????????????????????????????????????

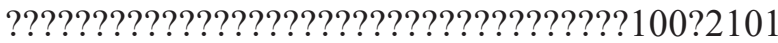
?001????????????????????????????????????????? ??????????????????????????????????????????? ????????1???????1

Codification for CAPPA/UFSM 0200 on the dataset by Langer et al. (2017): ???????????????? ????????????????????????????????????????????? ????????????????????????????????????????????? ????????????????????????????????????????????? ????????????????????????????????????????????? ???????????????????????????????????????????? ????????????????????????????????????????????? ????1000?0??1??2011?00000???011???????????? ????????????????????????????????????????????? ???????????????????????????????????????????? ?????????????????????????????????????

Codification for Chromogisaurus novasi on the dataset by Langer et al. (2017): ???????????? ??????????????????????????????????????????? ??????????????????????????????????????????? ????????????????????????????????????????????? ??????????????????????????????????????????? ????????????????????????????????1???????????? ???????????????????????????????????????????

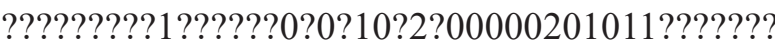

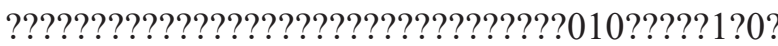


MAURÍCIO S. GARCIA et al.

?0????1101??????2010101100?00000010100???? ????????????????????????0???0?1??????????????

Codification of the added character (257) for all operational taxonomic units on the dataset by Cabreira et al. (2016):

(?): Lagerpeton chanarensis, Dromomeron gregorii, Dromomeron romeri, Marasuchus lilloensis, Saltopus elginensis, Lewisuchus admixtus, Pseudolagosuchus major, Asilisaurus kongwe, Diodorus scytobrachion, Eucoelophysis baldwini, Sacisaurus agudoensis, Pisanosaurus mertii, Scutellosaurus lawleri, Lesothosaurus diagnosticus, Sanjuansaurus gordilloi, Pampadromaeus barberenai, Chindesaurus
A DINOSAUR ILIUM FROM THE LATE TRIASSIC OF BRAZIL

brianmalli, Liliensternus liliensterni, 'Syntarsus' kayentakatae, Zupaysaurus rugeiri, Daemonosaurus chauliodus, Petrified forest theropod, Dilophosaurus wetherelli.

(0): Euparkeria capensis, Ixalerpeton polesinensis, Silesaurus opolensis, Eocursor parvus, Herrerasaurus ischigualastensis, Staurikosaurus pricei, Panphagia protos, Eoraptor lunensis, Buriolestes schultzi, Pantydraco caducus, Efraasia minor, Plateosaurus, Tawa hallae, Eodromaeus murphy, Coelophysis bauri, Syntarsus rhodesiensis.

(1): Saturnalia tupiniquim, Chromogisaurus novasi, CAPPA/UFSM 0200. 